\title{
Effect of Intercrops on Apple Production cv. Red Delicious
}

\author{
Rifat Bhat", Sharbat Hussain, Muzaffara Akhter, M. K. Sharma, \\ Nawsheen Nazir, Aroosa Khalil, Shabir. A. Bangroo and A. Raouf Malik
}

Sher-e-Kashmir University of Agricultural Sciences and Technology of Kashmir, Shalimar, Srinagar, Jammu and Kashmir-190025, India

*Corresponding author

A B S T R A C T

\begin{tabular}{|c|c|}
\hline & \multirow{6}{*}{$\begin{array}{l}\text { An experiment was conducted to assess the effect of different intercrops like maize, pea, } \\
\text { strawberry, cabbage, red clover, French bean, oats and maize on apple production cv Red } \\
\text { Delicious under Kashmir conditions. The results obtained revealed significant } \\
\text { improvement in apple trees intercropped with legumes followed by control and non- } \\
\text { legume type crops. Flowering occurred earlier in pea ( } 44.44 \text { days from reference date), } \\
\text { followed by red clover ( } 44.32) \text { and French bean }(48.32) \text {. Per cent fruit set and fruit } \\
\text { maturity (DAFB to harvest) occurred earlier in apple trees intercropped with pea (12.91\%, } \\
179.50) \text {, red clover }(11.88 \%, 182.10) \text { and French bean }(10.75 \%, 184.50) \text { than control } \\
(9.70 \%, 185.57) \text { and heavy feeder crops like maize }(6.12 \%, 187.22) \text {, oats }(6.61 \%, 186.07) \text {, } \\
\text { strawberry }(8.45 \%, 184.79) \text { and cabbage }(8.02 \%, 184.21) \text {. Fruit yield }(37.51 \mathrm{~kg} / \text { tree), fruit } \\
\text { weight }(155.72 \mathrm{~g}) \text {, fruit volume }\left(165.56 \mathrm{~cm}^{3}\right) \text { and leaf nutrient status, } \mathrm{N} \mathrm{P}, \mathrm{K}, \mathrm{Ca} \text { and } \mathrm{Mg} \\
\text { were found to be highest in trees intercropped with legumes than with the non }-\mathrm{legume} \\
\text { type of crops. The impact of intercrops on relative economic yield of apple (system } \\
\text { equivalent yield) revealed that the apple trees intercropped with pea had better benefit: cost } \\
\text { ratio (1.71) followed by cabbage }(1.41) \text {, red clover }(1.40) \text { and French bean }(1.39) \text { than } \\
\text { clean cultivation (1.34). }\end{array}$} \\
\hline Keywords & \\
\hline $\begin{array}{l}\text { Apple, Intercrops, } \\
\text { Yield, Economics, } \\
\text { Leaf nutrient status, } \\
\text { Red Delicious }\end{array}$ & \\
\hline Article Info & \\
\hline $\begin{array}{l}\text { Accepted: } \\
17 \text { May } 2018 \\
\text { Available Online: } \\
\text { 10 June } 2018\end{array}$ & \\
\hline & \\
\hline
\end{tabular}

\section{Introduction}

The Jammu and Kashmir state enjoys a unique and varied climate in the Indian subcontinent for successful production of temperate fruits particularly apple. In spite of the fact that this is the only state where yield of apple varieties is highest in the country yet it compares poorly to the yields obtained by other horticulturally advanced countries. One of the main reasons for low productivity is the low availability of essential nutrients, as the farmers are supplying only $\mathrm{N}, \mathrm{P}$ and $\mathrm{K}$ fertilizers and that too indiscriminately and secondly the interspaces which are left as such, are timely covered with perennial weeds which compete with essential nutrients and moisture, thereby reducing their availability. These perennial weeds actually go deeper into the soil for moisture, and lot of water is also transpired from them. Due to this crop-weed competition, fruit trees mostly suffer from water stress and also have an impact on yield and quality of fruits, (Derr 2001). So if the interspaces of orchards are utilized by growing different intercrops, that are compatible with 
the main crop, they not only improve the physical conditions of soils but also enhances the uptake of moisture and nutrients. In India, the states of Jammu and Kashmir, Himachal Pradesh and Uttarakhand are main contributors of apple cultivation. However, Jammu and Kashmir state have major share with an area of 162971 ha and with the production of 1726834 metric tonnes (Anonymous, 2016-17). The most of the area occupied by this crop in the state is under rain fed conditions. The interspaces between the plants under such conditions not only go without productive use but also become vulnerable to weeds. So growing of intercrops within the interspaces not only provides additional crop, high economic returns but there will be also greater utilization of natural resources which enhances uptake of nutrients. Orchardists usually cultivate several crops in between tree spacing to avoid infestation of perennial weeds. These perennial weeds go deeper into soil for moisture and transpire a lot of water. Due to crop-weed competition fruit trees suffer from water stress so cause a setback to fruit yield and quality. Intercropping is, therefore, one of the most important factors of orchard soil management system (Derr, 2001). So once it is practised, it will be the top agricultural option for today and tomorrow as well as for achieving an upswing growth rate in agriculture on a sustainable basis ensuring food and nutritional security, environmental safety (Vandermeer, 1989), achieving social and gender equity, generating employment and alleviating poverty.

So, this system seems to be the possible solution to meet the continuous increase in demand for food, stability of income and diverse requirements of food, thereby improving the nutrition for small scale farmers with limited resources. Thus keeping in view the above points, the present investigations was carried out to determine the effect of Intercrops on Apple production cv. Red
Delicious, out at Ambri Fruit Research Station, Pahnoo, Shopian SKUAST-Kashmir during the year 2008-2009.

\section{Materials and Methods}

\section{Research and Climate}

The investigations were carried out at the Experimental Farm of SKUAST-Kashmir, Ambri Apple Research Station, Pahnoo, Distt. Shopian (Jammu and Kashmir) during the years 2008 and 2009 on apple cv. Red Delicious. The climate is temperate cum Mediterranean and of continental type. Winter is severe extending over 100days from the middle of December to March, during which the temperature often goes below the freezing point and the whole valley remains covered with snow. The valley is marked by extreme of temperature, ranging from a maximum of $35^{\circ} \mathrm{C}$ in summer to a minimum of $-10^{\circ} \mathrm{C}$ in winter. The annual mean temperature is $15^{\circ} \mathrm{C}$. The climate is cold and rainfall is optimum, well distributed about $80 \mathrm{~cm}$ per annum, mostly in the form of snow during winter. (Anonymous, 2015). An experiment was laid out in a randomized block design with eight treatment combinations. There were three replications and 4 plants per plot.

\section{Phenological and Fruit Characteristics}

Floral character like initial bloom and full bloom were recorded as dates of opening of flowers (about 10\% flowering in initial bloom and about $80 \%$ in full bloom). The recorded dates were converted into days after reference date which was fixed arbitrarily as March $1^{\text {st }}$. Per cent fruit set of each experimental plot was calculated at fruitlet stage by using the formula suggested by Westwood (1993). Fruit maturity was recorded from date of full bloom to the date when the fruit was actually harvested. Fruit yield was calculated by weighing all the fruits harvested individually 
from each experimental tree and average yield was expressed as $\mathrm{kg} /$ tree. Fruit weight was determined by individually weighing the fruits obtained from each experimental plant on a common monopan balance and the average weight was recorded by using the procedure given by Rangana (1986), Fruit volume was determined by water displacement method.

\section{Leaf Characteristics}

Leaf total nitrogen content was determined by Micro-Kjeldhal method (A.O.A.C. 1990), total phosphorus by vanado-molybodophophoric yellow colour method (Jackson 1967) and total potassium by flame photometer. $\mathrm{Ca}^{2+}$ and $\mathrm{Mg}^{2+}$ ions in leaf were estimated on Atomic Absorption Spectrophotometer. The data obtained was subjected to the statistical analysis in S-plus software.

\section{Results and Discussion}

\section{Phenological Characteristics}

The data present in Table 1 revealed that the blooming of apple trees intercropped with pea started from 43.18 days after reference date (i.e., $1^{\text {st }}$ March) but in case of apple plants intercropped with maize, initial bloom appeared after completion of 49.88 days from the reference date. Full bloom also occurred earlier in apple trees intercropped with legume and late with heavy feeder crops like maize, oats, cabbage and strawberry. This might be due to the reason that adequate quantity of $\mathrm{N}$, $\mathrm{P}$ and $\mathrm{K}$ are contributed by leguminous crops which are capable of producing large amount of carbohydrates and thus encourages fruit bud formation. In crops like maize, oats etc., uptake of nutrients gets restricted as these heavy feeder crops transpire more and extract huge amount of moisture from the soil, thereby affecting the nutrient availability and their uptake. These findings are in accordance with Kanwar (2000).
Apple trees intercropped with leguminous crops like pea, red clover and French bean resulted in higher fruit set and early fruit maturity than with heavy feeder crops like maize, oats, cabbage, strawberry and control (clean cultivation) (Table 1). However control (clean cultivation) recorded more per cent fruit set and early fruit maturity than heavy feeder crops.

This might be due to the physical improvement of soil which might have facilitated the development of roots and provided better conditions for uptake of nutrients. while in case of heavy feeder crops, due to the competition for nutrients there will be low nutrient availability to apple trees which in turn reduces the rate of metabolism, consequently there will be less synthesis of carbohydrates and due to the deficiency of nutrients opening of buds occur slowly taking more time to come into full bloom, thereby enhancing the number of days to mature fruits. These results are in conformity with Delip (1967), Hill-Cottingham and Williams (1967) and Gao et al., (2013).

\section{Fruit Characteristics}

Average fruit yield was higher in apple trees intercropped with leguminous crops than the apple trees intercropped with control (clean cultivation) and heavy feeder crops (Table 2). Highest fruit yield was observed in apple trees intercropped with pea followed by red clover, French bean, control (clean cultivation), strawberry, cabbage and oats, while lowest fruit yield was observed in trees intercropped with maize. This might be due to the reason that leguminous crops increase the absorptive capacity of water and nutrient in upper fertile layers of soils thereby reducing evaporation. They also maintain slightly higher temperature which could essentially help in uptake of nutrients and increases the root concentration on the surface soils. 
Table.1 Effect of intercrops on initial and full bloom, per cent fruit set and fruit maturity of apple cv. Red Delicious

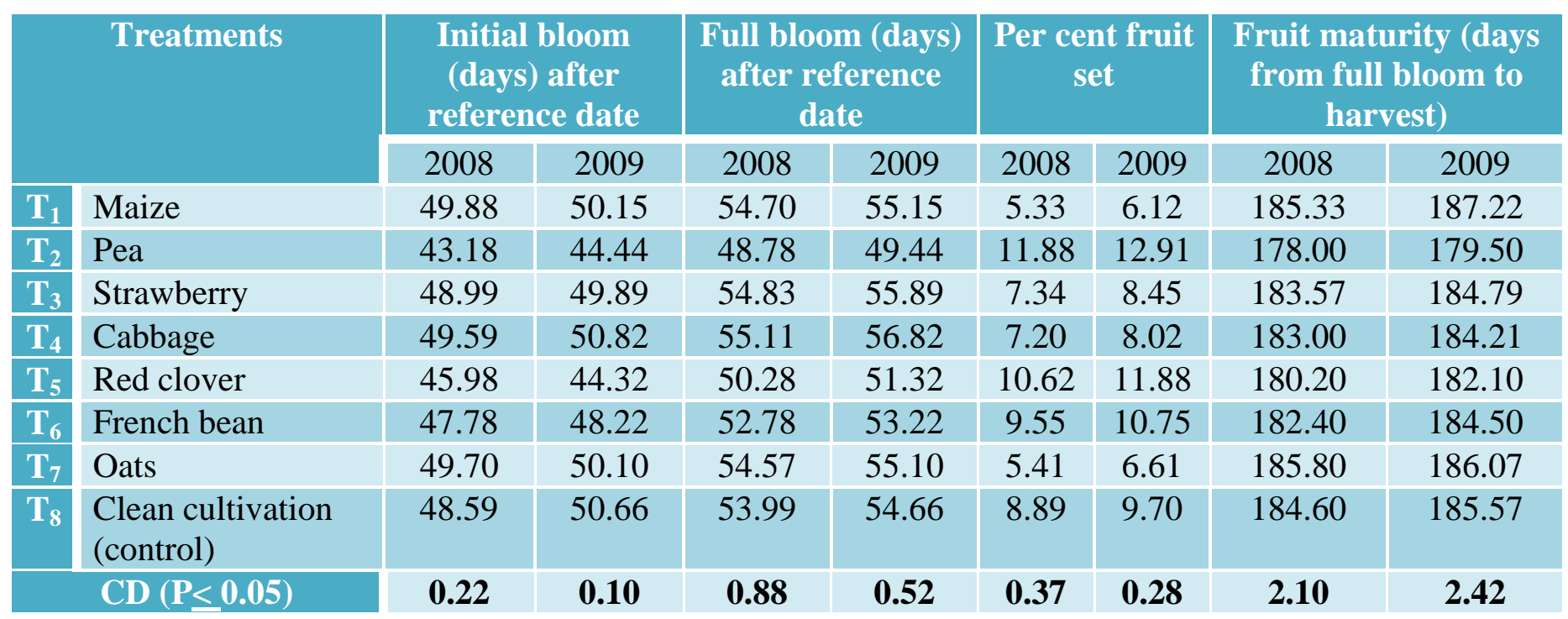

Table.2 Effect of intercrops on fruit yield, fruit weight and fruit volume of apple cv. Red Delicious

\begin{tabular}{|c|c|c|c|c|c|c|c|}
\hline \multirow{2}{*}{\multicolumn{2}{|c|}{ Treatments }} & \multicolumn{2}{|c|}{ Fruit yield (kg/tree) } & \multicolumn{2}{|c|}{ Fruit weight (g) } & \multicolumn{2}{|c|}{ Fruit volume $\left(\mathrm{cm}^{3}\right)$} \\
\hline & & 2008 & 2009 & 2008 & 2009 & 2008 & 2009 \\
\hline $\mathbf{T}_{1}$ & Maize & 28.56 & 29.99 & 137.69 & 138.88 & 149.97 & 150.02 \\
\hline $\mathbf{T}_{2}$ & Pea & 35.17 & 37.51 & 153.66 & 155.72 & 163.86 & 165.56 \\
\hline $\mathbf{T}_{3}$ & Strawberry & 29.57 & 31.79 & 141.72 & 142.55 & 152.72 & 153.97 \\
\hline $\mathbf{T}_{4}$ & Cabbage & 29.00 & 30.57 & 140.50 & 141.43 & 151.26 & 152.14 \\
\hline $\mathrm{T}_{5}$ & Red clover & 34.87 & 35.62 & 148.24 & 150.29 & 160.66 & 162.12 \\
\hline $\mathrm{T}_{6}$ & French bean & 32.57 & 33.32 & 144.82 & 146.86 & 158.22 & 160.01 \\
\hline $\mathbf{T}_{7}$ & Oats & 28.67 & 29.22 & 138.66 & 139.01 & 150.88 & 151.58 \\
\hline$\overline{\mathbf{T}_{8}}$ & $\begin{array}{l}\text { Clean cultivation } \\
\text { (control) }\end{array}$ & 30.27 & 32.02 & 142.12 & 143.88 & 155.29 & 156.52 \\
\hline & $\mathrm{CD}(\mathrm{P}<0.05)$ & 2.15 & 2.20 & 0.32 & 0.46 & 0.25 & 0.36 \\
\hline
\end{tabular}


Table.3 Effect of intercrops on leaf N, P, K status of apple cv. Red Delicious

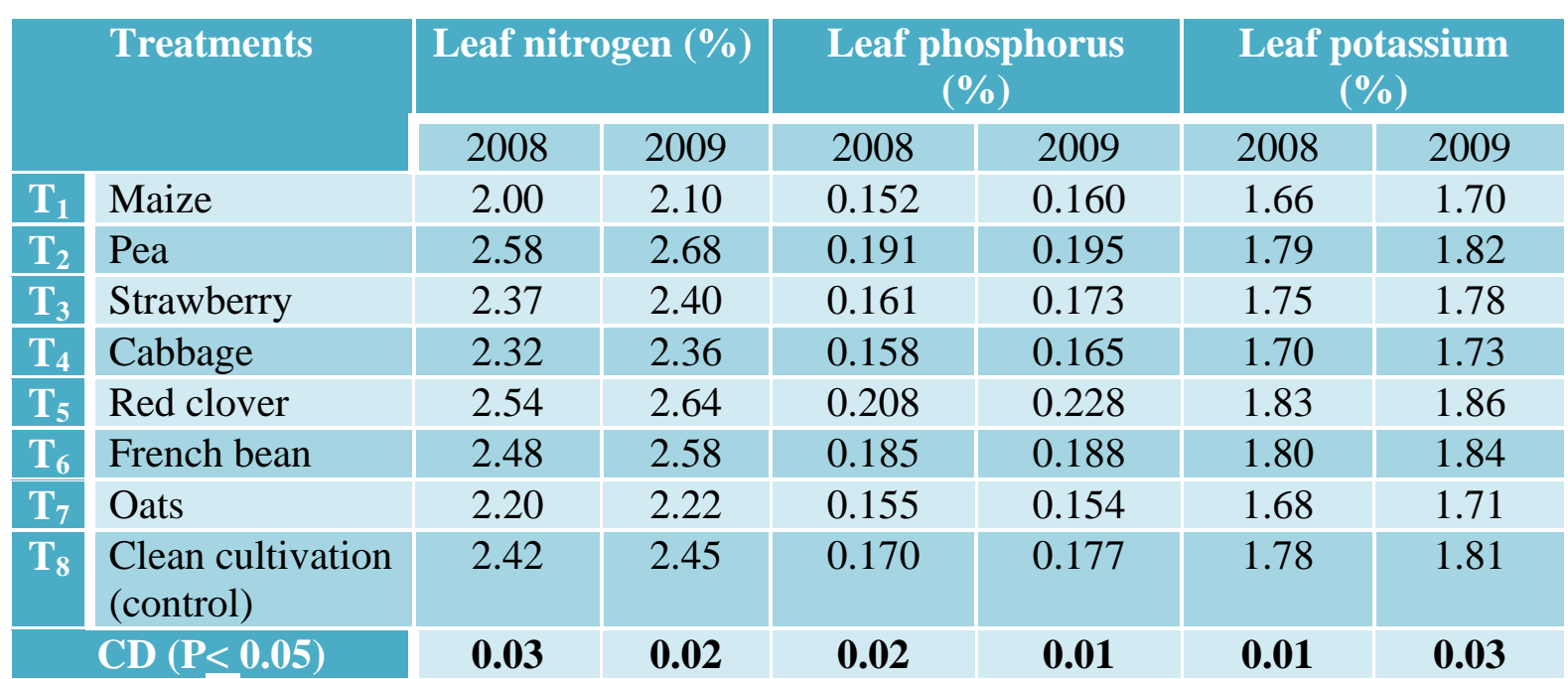

Table.4 Effect of intercrops on leaf $\mathrm{Ca}$ and $\mathrm{Mg}$ status of apple cv. Red Delicious

\begin{tabular}{|l|l|c|c|c|c|}
\hline \multirow{2}{*}{ Treatments } & \multicolumn{2}{|c|}{ Leaf calcium $(\%)$} & \multicolumn{2}{|c|}{ Leaf magnesium $(\%)$} \\
\hline & 2008 & 2009 & 2008 & 2009 \\
\hline $\mathrm{T}_{1}$ & Maize & 1.66 & 1.68 & 0.25 & 0.27 \\
\hline $\mathrm{T}_{2}$ & Pea & 1.80 & 1.82 & 0.38 & 0.40 \\
\hline $\mathrm{T}_{3}$ & Strawberry & 1.72 & 1.74 & 0.29 & 0.31 \\
\hline $\mathrm{T}_{4}$ & Cabbage & 1.70 & 1.72 & 0.28 & 0.30 \\
\hline $\mathrm{T}_{5}$ & Red clover & 1.92 & 1.94 & 0.35 & 0.37 \\
\hline $\mathrm{T}_{6}$ & French bean & 1.86 & 1.88 & 0.32 & 0.34 \\
\hline $\mathrm{T}_{7}$ & Oats & 1.68 & 1.70 & 0.26 & 0.28 \\
\hline $\mathrm{T}_{8}$ & Clean cultivation & 1.74 & 1.76 & 0.30 & 0.32 \\
\hline & (control) & & & & $\mathbf{0 . 0 5}$ \\
\hline
\end{tabular}


Table.5 Effect of intercrops on relative economics of apple cv. Red Delicious (system equivalent yield)

\begin{tabular}{|c|c|c|c|c|c|c|c|c|c|c|}
\hline \multicolumn{2}{|c|}{ Treatment } & $\begin{array}{l}\text { Pooled } \\
\text { apple } \\
\text { yield } \\
\text { (kg/ha) }\end{array}$ & $\begin{array}{c}\text { Yield of } \\
\text { intercrop } \\
\text { (q/ha) }\end{array}$ & $\begin{array}{l}\text { Income } \\
\text { obtained } \\
\text { from } \\
\text { intercrops }\end{array}$ & $\begin{array}{c}\text { Apple } \\
\text { equivalent } \\
\text { inter crop } \\
\text { yield (kg/ha) }\end{array}$ & $\begin{array}{l}\text { Total } \\
\text { system } \\
\text { yield } \\
\text { (kg/ha) }\end{array}$ & $\begin{array}{l}\text { Total cost of } \\
\text { cultivation/ha }\end{array}$ & $\begin{array}{l}\text { Gross } \\
\text { return } \\
\text { (Rs/ha) }\end{array}$ & $\begin{array}{c}\text { Net } \\
\text { return } \\
\text { (Rs/ha) }\end{array}$ & $\begin{array}{c}\text { Benefit } \\
\text { cost } \\
\text { ratio }\end{array}$ \\
\hline $\mathbf{T}_{1}$ & Maize & 7436.00 & 30 & 24000 & 600.00 & 8036.00 & 140426.0 & 321440 & 181014.0 & 1.28 \\
\hline $\mathbf{T}_{2}$ & Pea & 10246.60 & 21 & 52500 & 1312.50 & 11559.10 & 170550.0 & 462364 & 291814.0 & 1.71 \\
\hline $\mathbf{T}_{3}$ & Strawberry & 7982.00 & & & 2200.00 & 10182.00 & 197582.0 & 407280.0 & 209698.0 & 1.06 \\
\hline i) & Fruit & & 12 & 48000 & & & & & & \\
\hline ii) & Runner & & 40,000 & 40000 & & & & & & \\
\hline $\mathbf{T}_{4}$ & Cabbage & 7701.20 & 1.25 & 75000 & 1875.00 & 9576.20 & 158620.0 & 383048 & 224428.0 & 1.41 \\
\hline $\mathbf{T}_{5}$ & Red clover & 9705.80 & 100 & 10000 & 250.00 & 9955.80 & 165837.0 & 398232 & 232395.0 & 1.40 \\
\hline $\mathrm{T}_{6}$ & $\begin{array}{l}\text { French } \\
\text { bean }\end{array}$ & 8954.40 & 20 & 50000 & 1250.00 & 10204.40 & 170550.0 & 408176 & 237626.0 & 1.39 \\
\hline $\mathbf{T}_{7}$ & Oats & 7675.20 & 170 & 17000 & 425.00 & 8100.20 & 111729.0 & 324008 & 182279.0 & 1.28 \\
\hline $\mathbf{T}_{8}$ & $\begin{array}{l}\text { Clean } \\
\text { cultivation } \\
\text { (control) }\end{array}$ & 7969.00 & - & - & - & - & 145000 & 339560.0 & 194560 & 1.34 \\
\hline
\end{tabular}

*Maintenance cost of established orchard Rs. 5, 000/kanal 
The production can also be influenced by species, orchard site, pruning procedures, pests and diseases and above all the rootstocks. These findings are in congruence with Neilson and Hogue (1985).

Fruits harvested from apple trees intercropped with legumes recorded maximum fruit weight and fruit volume. However, control (clean cultivation) showed greater fruit weight as compared to heavy feeder crops like strawberry, cabbage, oats and maize (Table 2). This may be due to the reason that heavy feeder crops (maize and oats) compete strongly for moisture and nutrients with the apple tree as they transpire more water (moisture), resulting in poor quality fruits while $\mathrm{N}$ fixation by legumes results in higher availability of both $\mathrm{N}$ and moisture as they increase water holding capacity of soil which might have helped to increase uptake of nutrients and thus increased dry matter accumulation. These results are in congruence with Yankovoi (1983).

\section{Leaf Characteristics}

Highest leaf $\mathrm{N}$ and $\mathrm{Mg}$ was recorded in apple trees intercropped with pea while as lowest was recorded with maize (Table 3 \& 4). Leaf $\mathrm{P}, \mathrm{K}$ and $\mathrm{Ca}$ was recorded highest in apple trees intercropped with red clover followed by French bean, pea, control (clean cultivation), strawberry, cabbage, oats and maize. This might be due to the fact that leguminous crops like pea have a symbiotic relationship with rhizobium species which is capable of fixing large amount of atmospheric $\mathrm{N}$ thus increasing available soil $\mathrm{N}$. These results are in line with Fisenko (1969), while in case of leaf $\mathrm{P}, \mathrm{K}$ and $\mathrm{Ca}$ this may be due to higher availability of moisture by clovers, as they can penetrate into the deeper layers of soils for extraction of moisture which might have facilitated the uptake of nutrients and their uptake is correlated with the availability of
$\mathrm{H}_{2} \mathrm{O}$. These results are in conformity with Neilson and Hogue (1985).

\section{Benefit: Cost Ratio}

Highest benefit: cost ratio was recorded in apple trees intercropped with pea (1.71) followed by cabbage (1.41), red clover (1.40) and French bean (1.39), respectively (Table 5). This was mainly due to additional yield of pea, seed production of cabbage, red clover and French bean and also their better marketing price. These findings are in congruence with Kishore et al., (1997).

\section{References}

Anonymous. 2016-17. Statement showing area, production and productivity of fruits in $J \& K$ state. Department of Horticulture.

AOAC. 1990. Methods of analysis. $4^{\text {th }}$ Edition. Association of Official and Agricultural Chemists, Washington, DC 20044.

Delip, A.V. 1967. The effect of supplying nitrate at different seasons on the growth, blossoming and nitrogen content of young apple trees in sand culture. Journal of American Society for Horticultural Science 42: 149-67.

Derr, J.F. 2001. Biological assessment of herbicides use in apple production II. Estimated impacts following loss of specific herbicides. Horticulture Technology 11(1): 20-5.

Gao, L., $\mathrm{Xu} \mathrm{H}, \mathrm{Xi}$. W. and Bao, B. 2013.Intercropping competition between apple trees and crops in agroforestry systems on the Loers plateau of China. PLOS ONE 8(7): e70739.

Hill-Cottingham, D.G. and Williams, R.R. 1967. Effect of time of application of fertilizer nitrogen on the growth, flower development and fruit set of maiden 
apple trees var. Lord Lambourne and on the distribution of total nitrogen within the tree. Journal of American Society for Horticultural Science 42: 319-38.

Jackson, M.L. 1967.Soil chemical anaysis. Asia Publishing House, Bombay, p. 48.

Kanwar, S.M. 2000. Fruit bud formation, pollination and fruitset. In: Apples Production Technology and Economics. Tata McGraw Hill Publishing Company Limited, New Delhi, pp 159-62.

Kishore, D.K., Sharma, Y.P. and Pramanick, K.K. 1997. Prospects of economizing in the use of nitrogenous fertilizers in apple orchards intercrops with Trifolium repens. Progressive Horticulture 29(12): 88-92.

Munde, G.R., Hiwale, B.G., Nainwad, R.V. and Dheware, R.M.2017. Effect of Intercrops on growth and yield of Custard Apple. Bioscan 6(1): 29-31.

Neilson, G.H. and Hogue, E.J.1985. Effect of orchard soil management on growth and leaf nutrient concentration of young dwarf 'Red Delicious' apple trees. Canadian Journal of Soil Science 65: 309-15.
Peryea, L.L. 1991. Preharvest Ca sprays and apple firmness. Good Fruit Grower 42(13): 12-15.

Rangana, S. 1986. Handbook of analysis and quality control for fruit and vegetable products. $\left(2^{\text {nd }}\right.$ Edition $)$. Late McGrew Hill Publishing Co., New Delhi, pp. 190-210.

Singh, M.K., Kumar, P. and Prasad, S.K. 2014. Agri-horti systems and weed management practices effect of growth and yield of Mungbean. Bioscan 9(4): 1449-1453.

Trenbath, B.R.1976. Performance of turmeric in Cashew plantation as intercrop compared to sole cropping Bioscan 8(4): 1237-1239.

Vandermeer, J. 1989. The ecology of intercropping. Cambridge University Press, New York.

Westwood, M.N. 1993. Temperate Zone Pomology. (Ed. H. Freeman and Company). San Francisco, p. 523.

Yankovoi, M.I. 1983. Effect of herbicide application and plastic mulching on growth and cropping in a young apple orchard. Sadovodstvo, Vinogradarstvoi Vinodihe Maldavii 12: 50.

\section{How to cite this article:}

Rifat Bhat, Sharbat Hussain, Muzaffara Akhter, Nawsheen Nazir, Aroosa Khalil, Shabir. A. Bangroo and A. Raouf Malik. 2018. Effect of Intercrops on Apple Production cv. Red Delicious. Int.J.Curr.Microbiol.App.Sci. 7(06): 1543-1550.

doi: https://doi.org/10.20546/ijcmas.2018.706.184 